\title{
A HEBREW PARAPHRASE OF THE HIPPOCRATIC OATH (FROM A FIFTEENTH-CENTURY MANUSCRIPT)
}

\author{
by \\ S. S. KOTTEK, J. O. LEIBOWITZ, and B. RICHLER*
}

\section{DESCRIPTION OF THE MANUSCRIPT**}

MS No. MIC. 2469 in the Jewish Theological Seminary of America Library in New York (formerly E. N. Adler collection no. 2405) is a collection of nearly forty short works on philosophy, kabbala, and Talmud written in a fifteenth-century rabbinical Byzantine script. In cataloguing the microfilm copy of the manuscript at the Institute of Microfilmed Hebrew Manuscripts in the Jewish National and University Library in Jerusalem, ${ }^{1}$ I was able to identify one short piece as a Hebrew adaptation of Hippocrates' oath, apparently the first such text to come to light.

The oath in its Hebrew version is found on page $212^{\mathrm{v}}$ of the manuscript under the heading Musar he-hasid Abukrat. It is immediately preceded by the following works (in Hebrew): Liber de Pomo attributed to Aristotle in Abraham ben Hisdai's wellknown translation (fols. 203 $-207^{\mathrm{V}}$ ); an ethical letter, also attributed to Aristotle in Judah al-Harizi's translation from the Arabic version by a certain $\mathrm{Ali}^{2}$ (fols. $209^{\mathrm{r}}-211^{\mathrm{V}}$ ); and a prayer attributed to Socrates in the translation of Zerabia (fol. 212'). It may be noted that in our manuscript the names of the translators of the two latter works were omitted even though they appear in other medieval manuscripts of the same works.

Our codex is briefly described in the catalogue of E. N. Adler's collection of manuscripts, ${ }^{3}$ but no mention is made of Hippocrates' oath. The same is true of the more detailed handwritten description attached to the manuscript. At least three scholars made use of our codex in their publications, and one of them, A. Marx, added a short description of the codex to one of his articles, ${ }^{4}$ but none of them made mention of our text.

*Samuel S. Kottek, M.D., Head, Division of the History of Medicine, The Hebrew University, Hadassah Medical School, P.O.B. 1172, Jerusalem, Israel.

J. O. Leibowitz, M.D., Emeritus Professor, Yordei Hasira Street 3, Jerusalem, Israel.

Benjamin Richler, M.L.S., Assistant Director of the Institute of Microfilmed Hebrew Manuscripts, Jewish National Library, Jerusalem, Israel.

**By Benjamin Richler.

1 Microfilm no. 28722.

Cf. M. Steinschneider, Die hebräischen Ubbersetzungen des Mittelalters und die Juden als Dolmetscher, Berlin, 1893, pp. 354-355. (Reprinted Graz, Akademische Druck- und Verlagsanstalt, 1956.)

- Catalogue of Hebrew manuscripts in the collection of Elkan Nathan Adler, Cambridge, 1921, pp. 82-83.

- Marx described the codex on pages 339-340 of his article 'The correspondence between the Rabbis of Southern France and Maimonides about astrology', in Hebrew Union College of America Annual, 1926, III. M. Higger published 'Yarhi's commentary on Kallah Rabbati' in Jewish quart. Rev., 1933-34, 24: 331-348, on the basis of this manuscript, and Marx published some of his 'Texts by and about Maimonides' in ibid., 1934-35, 25: 406-428. Marx also published his edition of Shisha 


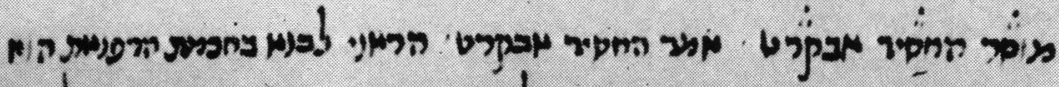

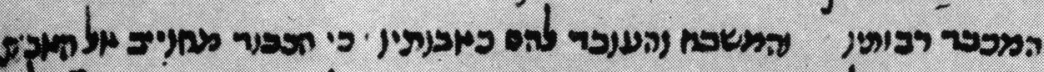

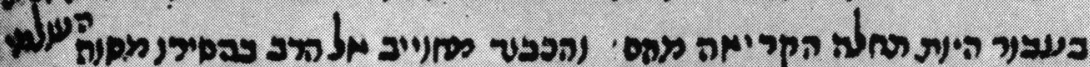

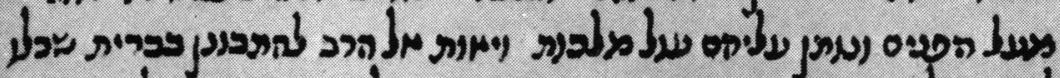
a

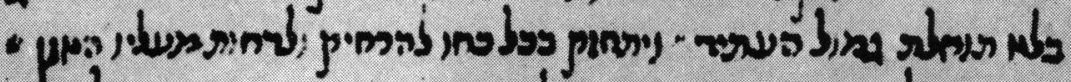

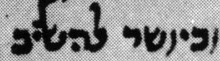

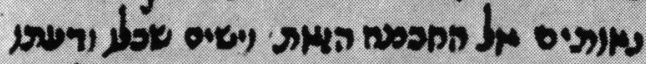

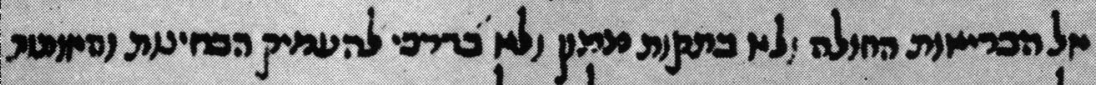

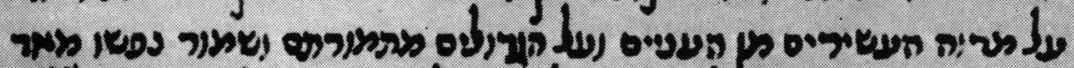

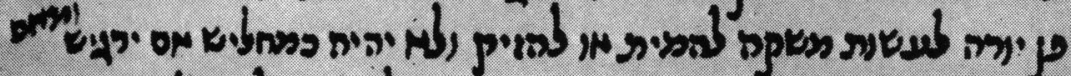

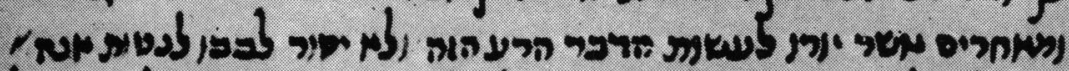

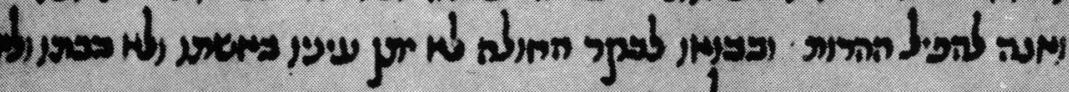

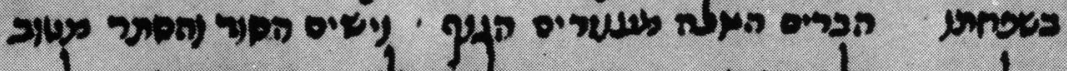
-

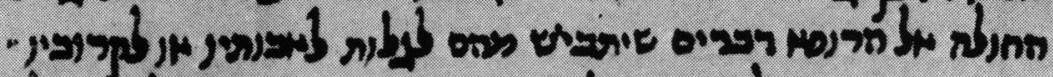

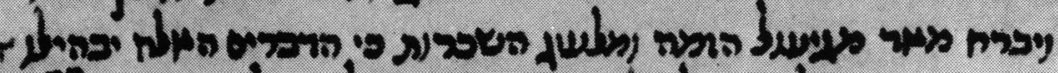

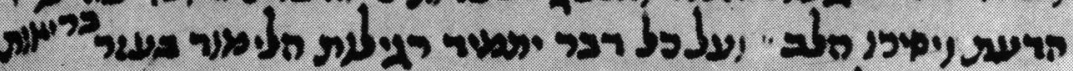

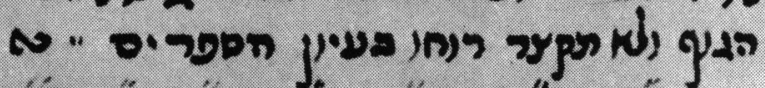

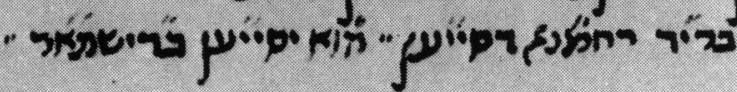

Hebrew adaptation of the Hippocratic oath. From Ms. JTS Mic. 2469, p. $212^{\mathrm{v}}$, in the Jewish Theological Seminary of America Library, New York. 


\section{Texts and Documents}

MS New York JTS Mic. 2469 is a paper manuscript consisting of 286 folios. It measures $211 \times 142 \mathrm{~mm}$, the area of the text being $140 \times 88 \mathrm{~mm}$. The condition of the binding does not allow the determination of the number of leaves in each quire. There are generally twenty-nine lines on each page, but some have twenty-seven and others thirty-one. Some of the pages are bound out of place and others are missing altogether. The first and last leaves are among those missing. The scribe of the codex wrote two colophons, from which we learn that he was called Dosa ben Joseph and that he wrote the manuscript in 1461 in Constantinople. In the second colophon (fol. 190') he writes explicitly that the manuscript was written "by the pen of Dosa the lowly, the son of the late Joseph in the year 5221 of the Creation [=1461], in Constantinople in the month of Elul". In an earlier colophon in verse (fol. 97 ), in which the name Dosa appears only as an acrostic, he states that he completed Maimonides' commentary on the Mischnaic tractate Avot in the month of Adar (six months before Elul) in the same year, 5221, at "Poli", which is probably a shortened form of Constantinople which Dosa used because it conformed to the metrics of his verses. ${ }^{5}$

Dosa seems to have written the manuscript for his own personal use. He appears to have been a fairly learned scholar and probably copied for himself texts which he needed in order to pursue his studies. Throughout the manuscript numerous notes (some of which were partly cut away when a careless binder sliced the outer edges of the manuscript) written by him, sometimes in a cursive script, support these suppositions, On fol. 105v, for example, he writes: "I found a commentary on the tractate Avot and I culled from it a few passages." Dosa showed more than a passing interest in the texts he copied. On fol. $138^{v}$ he writes: "Afterwards, I checked other books and found that the text agrees with what I wrote." On numerous passages he added in the margins variant readings from other manuscripts.

We know very little more about Dosa ben Joseph. He appears to have been a well-travelled man. On fols. $97^{\mathrm{v}}$ and $98^{\mathrm{r}}$ he added a number of verses which he composed; one was written in Sofia, another when he came to Constantinople with his brother, Moses, and yet another when he crossed the sea from Chios to Candia. He does not seem to have been a professional scribe, for we know of no other manuscript copied by him.

The translator of our version remains anonymous. It is not possible to attribute the version to Dosa himself. With the exception of the few short verses already mentioned, none of the works in the manuscript was composed by him. A note written in the margin of fol. $212^{\mathrm{v}}$ by Dosa himself attests to the fact that he copied the text from another manuscript. Unfortunately, most of the note has been cut away, but the remaining words "... the language ... it seems to me ... an error" show that Dosa was unhappy with the reading of one of the words in the text and attributes the difficulty to an error on the part of an earlier scribe. The note refers

Meshallim, Berlin, 1925 (in Hebrew) from this same manuscript. More recently J. Blau used material in the manuscript for his edition of Maimonides' responsa (cf. Hierosolymis, 1961, vol. iii, p. 26).

- Much of the palaeographical data in this article is based on the description of the manuscript made by the staff of the Hebrew Palaeography Project, a joint project of the Israel Academy of Sciences and the Centre National de la Recherche Scientifique in Paris. 


\section{Texts and Documents}

to an unintelligible word over which two dots were added to signify that it was the subject of a marginal note. Dosa, then, obviously copied the text from another manuscript and was not the author of the adaptation.

\section{ENGLISH TRANSLATION AND CRITICAL STUDY*}

\section{THE TEXT}

The Morals [Moral Precepts] of the Righteous ${ }^{6}$ Hippocrates.

Said the Righteous Hippocrates:

[1] He is considered worthy of entering into the Science of Medicine, who respects his Teachers and who praises his Teachers, praises and assists them as he does for his Parents. The Parents must be respected because the beginning of instruction? comes from them. And the Teacher must be revered because he removes from [the student's] face the wordly veil ${ }^{8}$ and bestows on him the yoke of Royalty. ${ }^{9}$

And the Teacher should scrutinize his mind ${ }^{10}$ with respect to the covenant, to select a pupil suitable [for these studies] and virtuous in his behaviour.

And he will guide him along the path of truth and without remuneration, and without expectation of any future reward.

And he will firmly and resolutely keep at a distance and repel anyone who is not suitable for this Science.

[2] He will bestow his wisdom and his knowledge $\ldots{ }^{11}$ and forthrightly bring back to health the sick-not in hope of payment.

And he should refrain from pursuing a more thorough examination and search for symptoms in dealing with the wealthy than with the poor, or with noblemen in hope of reward. ${ }^{12}$

[3] And he will take great care not to give instructions in the preparation of a potion

*By Samuel S. Kottek.

- The Righteous. The Hebrew word hassid means a man who acts in a straight and moral manner. The same word has also a special meaning when applied by rabbinical authorities to a gentile (hassid ummōt ha-ölam). It is applied to a non-Jew who accepted to live according to the seven laws given to Noah in the Scriptures.

"Instruction. It is written "Keriah", which means reading or calling, in fact: to notice with one's eyes or to express with one's voice some written document.

B The wordly veil. The face of the pupil is covered by a veil of ties to the surrounding world. The master explains to him that these ties are hindering his clear perception, and must be removed. This veil (masvé) is a reminiscence taken from the Scriptures (Exod. 34: 33-35). The face of Moses was radiant when he came down from Mount Sinai, "but always, when he spoke to them, he put the veil back over his face....".

- The yoke of Royalty. Before teaching medicine, the master wants his pupil to accept the absolute authority of the Almighty. The master is then invested with part of this authority.

${ }^{10}$ To scrutinize his mind. It is not clear whether the teacher must ponder on the covenant into which his pupil will be accepted, or, more probably, if the master must examine the mind of his pupil in relation to the covenant.

${ }^{11}$ Here one word of the manuscript is missing. Perhaps the copyist was unable to read it or the translator unable to translate. It could have been an adverb, like "conscientiously".

12 The text says literally "and the great [men] for their reward". This reward could be either money, or special protection. 


\section{Texts and Documents}

causing death or injury, nor should he [become involved in a procedure] causing weakening to the patient if he feels [this to be] distasteful, ${ }^{13}$ or if he is induced to do such an evil deed.

[4] And he will not let his heart be led astray and be swayed into causing an abortion to a pregnant woman.

[5] When visiting his patient, he shall not cast his eye either upon his wife or upon his daughter, or upon his maid. ${ }^{14}$

All these things blind the body. ${ }^{15}$

[6] He will place secrecy and confidentiality among the best of his qualities, lest he should reveal a secret ailment after it has been divulged to him. For the patient often discloses to the physician matters which he is embarrassed to tell his parents or his relatives.

[7] And he will definitely abstain from the blemish of debauchery and the shame of drunkenness, because these trouble the $\operatorname{mind}^{16}$ and lead the heart astray.

[8] Above all, he should accustom himself to continual learning in order to help the body to health ${ }^{17}$ and should never weary of referring to books.

\section{DISCUSSION}

\section{THE MORALS [MORAL PRECEPTS] OF HIPPOCRATES}

This text is not actually an oath. There is only one allusion to the "covenant". Let us remember the oath of Asaf, which begins with the words: "This is the covenant which Asaf . . sealed with his pupils and had them swear on the following formula ..." In fact, the teacher is asked to be cautious not to accept a pupil who is not prepared to act according to the moral precepts prescribed.

The main rules of the Hippocratic oath are here retained, and in the same order: to help the sick; the interdiction of poisoning, abortion, and abuses on women; and secrecy. But many details have been changed, some items have been added and some important parts omitted.

\section{THE CHANGED PARTS}

\section{The first paragraph}

The Greek theological introduction has, of course, been dropped. The teacher [rav-and not more] has a religious role to play. The pupil must, as a first step in studying, accept the divine authority.

18 There is one word in the margin, which is very difficult to read, and we are not sure of our interpretation. It could also be understood: "and he should not give way if he feels [the situation to be] distasteful or if he is induced to do such an evil deed."

14 His maid. Hippocrates warned the physician not to "cast an eye" upon "man and woman, bond or free": homosexuality was then a real problem, but was not recalled in the Hebrew version.

${ }^{15}$ Blind the body. The obvious meaning of this remark is that his "putting an eye" on women would blind him in return. His corporeal as well as his moral self will be blinded, and he will no more be able to be a clear-sighted healer.

16 It troubles the mind. Debauchery and drunkenness both weaken the mind, and he would become unsteady and confused.

${ }^{17}$ To help the body to health. This could also be understood as the necessity of constant learning with the aid of good health: the physician must not sacrifice his health for the sake of learning. Still, the first interpretation seems more probable. 


\section{Texts and Documents}

There is no mention of the sons of the candidate. Hippocrates says: "I will impart knowledge of the Art to my sons, and the sons of my teachers ...." In our text, the student is asked to revere his teacher, and the teacher is asked to choose his pupils carefully and then to instruct them without payment. This is also an original statement, because Hippocrates only asked the physician to treat the sons of his master without any obligation. The author of our Hebrew version applies this principle without discrimination to any pupil, whom he thus regards as his own son. There is no mention of a "Guild of Physicians", but only of the relationship between teacher and student.

\section{The second paragraph}

The first aim of medicine is to restore the sick to health. But in our text there is an important addition: "not in hope of money", which is not in Hippocrates. This is perhaps meant as an answer to the main criticism against doctors-and especially by the gentiles against Jewish physicians-that of avarice.

Besides, in the Jewish law, the physician is placed in the same category as religious teachers and rabbis, who must not accept a reward for their professional services, but only a compensation for the time spent (cf. Shulhan Arukh, Y.D. 336,2). This was, of course, meant as a general principle, but the Jewish law tolerated the physician accepting payment from his patients.

\section{Poisoning}

Hippocrates says: “. . . nor suggest any such counsel”. In our text, the physician is warned never to agree "if somebody else tells him to do such an evil deed". The Jewish physician could sometimes have received such a command from his employer. Let us not forget that the Jewish physicians were more than once accused of poisoning.

\section{THE ADDED PARTS}

1. Not to differentiate between rich and poor, for instance by examining more thoroughly the rich or important patients. This care for social equality in treating the sick can be found in the covenant of Asaf (sixth to seventh century) and in the moral precepts of Isaac Israeli (tenth century): see his aphorism No. 30. Isaac, on the other hand, advises the physician to be eager to treat princes and nobles, because they will gladly pay him and praise his skill, whereas the poor will be angry once cured, because of the high fee (aphorism No. 46).

2. To keep away from debauchery and drunkenness, which act upon mind and heart. Hippocrates only calls for the physician's life to be "pure and sanctified", without more details. There is one allusion to depravity in Asaf ('zimah'): "You will never allow yourself . . . to favour any act of debauchery". Isaac Israeli, in his aphorism No. 27, advises the physician to be neither a glutton nor a drunkard.

3. The importance of constant learning is not in Hippocrates' oath, nor in Asaf's covenant, but it is twice mentioned in Isaac Israeli's aphorisms. He particularly stresses the importance of Galen (aphorism No. 6) and of studies in natural history and logic (aphorism No. 14).

THE OMITTED PARTS

1. Lithotomy: much has been written about this statement on the stone. Hippocrates 


\section{Texts and Documents}

seems to forbid any kind of operation, especially-or even-for the stone. He wants to leave the use of the knife to specialists. Edelstein* ascribes this really puzzling statement to Pythagorean influence.

Let us remember that Asaf only advised the physician not to operate with scalpel or cautery without thinking it over twice or thrice beforehand.

2. The adjuring formula, at the end of the text of Hippocrates, is, of course, omitted. The last advice given to our physician, never to get tired of learning throughout his lifetime, seemed to the author of our text a good and valid conclusion.

\section{CONCLUSION}

This Hebrew paraphrase of the Hippocratic oath, from a fifteenth-century manuscript, probably based on an earlier text, shows interesting inclusions and omissions, and should be taken in account amongst the numerous Jewish moral exhortations to the physicians.

*L. Edelstein, The Hippocratic oath, Baltimore, Md., The Johns Hopkins Press, 1943.

\section{HISTORICAL APPRAISAL**}

In the preceding paragraphs we have presented a detailed description of the recently discovered text with pertinent codicological and palaeographical data (B.R.). This was followed by an English translation of the Hebrew paraphrase of the Hippocratic oath, and a discussion based on a critical analysis of the manuscript, emphasizing addition to and omission of parts of the textus receptus of the oath (S.K.).

It seems appropriate to conclude the present paper by an assessment of the document and its place in the transmission of the classic oath in the Hebrew deontological medical literature (J.O.L.).

The discovery of the Hebrew text under discussion (B.R., summer 1976) was an unexpected event. While elements of the Hippocratic oath are easily identified in the oldest Hebrew oath of Asaf (seventh century), no Hebrew translation came to light in the host of medieval manuscripts examined by Steinschneider. ${ }^{18}$ The latter exhausted all Hebrew translations pertaining to Hippocrates, inclusive of indirect and presumptive ones. A more recent evaluation of the oath, especially in comparison with that by Asaf, was given by S. Pines in $1975,{ }^{19}$ just before our text was discovered. Although none of the present writers ${ }^{20}$ could refer to this paraphrase, mention of the relationship to the material of the Hippocratic oath was made.

As we do not know the identity of the author of our text, we must resort to an analysis of its style in order to approximate the chronology. While some phrases read easily, almost like contemporary language, others are decidedly archaic in structure. Throughout the text its wording leans on biblical patterns, much as does the

**By J. O. Leibowitz.

18 Steinschneider, op. cit., note 2 above, pp. 657-667.

$10 \mathrm{~S}$. Pines, 'The oath of Asaph the Physician and Johanan ben Zavda: its relation to the Hippocratic oath and the Doctrina Duarum Viarum of the Didaché, Proc. Israel Acad. Sci. Humanit., Jerusalem, 1975, 5: no. 9.

$20 \mathrm{~J}$. O. Leibowitz, 'Medical ethics and etiquette in Jewish history', reprinted from Medical Judaica, 1971,1 : no. 3. [Journal discontinued, reprints available from the author.] 


\section{Texts and Documents}

oath of Asaf. ${ }^{21}$ As to single words, for example, for one denoting "disease", the text uses madveh (Deut. 7:15, 28:60), a rare term from the Bible, which does not occur in later medieval medical Hebrew, where holi is the common designation. The style is an early post-biblical one much akin to that of Asaf. It is free of Arabisms introduced by the great translators (Ibn Tibbon family), thus we may presume that it was composed not later than about 1200 .

The title of our text is in Hebrew mussar, which we translated as "morals" or "moral precepts". It is the same word which has been used as caption of the Hebrew version of Hunein ibn Ishaq's (ninth century) Arabic collection of ancient Greek apophtegms (moral and other sentences). According to Steinschneider, ${ }^{22}$ this work was "one of the first non-Jewish Arabic books to be translated into Hebrew". The same word appears again in the title of Isaac Israeli's (tenth century) Mussar haRomf 'im (ethics and etiquette of the physicians), which was translated into English by S. Jarcho in 1944. ${ }^{23}$ The choice of the word mussar for a collection of medical ethical conduct rules in these works is a parallel to the usage in our text and can serve as a probable indication of its early date.

The lofty Hippocratic oath remained a living message in the historical tradition and transmission. To quote W. H. S. Jones: "There is nothing in the evidence to lead us to suppose that clauses were not added or taken away at various places and various times". ${ }^{24}$ This is clearly apparent in the foregoing discussion of our text. Suffice it to mention the pronounced philanthropic trend of the Christian Latin deontology (misericordia, caritas); in the Jewish sources; ${ }^{25}$ and in the Moslem writings, e.g. in the "Testament of Hippocrates" by Muhammad al-Gāfiqi, eleventh century, briefly mentioned by Deichgräber. ${ }^{26}$ In some smaller tracts of the Hippocratic corpus, though late and apocryphal, such as the Precepts (chapter VI) ${ }^{27}$ the lack of philanthropy and compassion in the original oath appears to have been overcome. ${ }^{28}$

In our text the injunction to treat and examine poor patients with no less assiduity than wealthy and noble ones, is contained in paragraph 2 of our English translation. It is expressed not in a theoretical way but reflecting actual medical practice. Characteristically it is part and parcel of the paraphrase and thus complements the Hippocratic oath.

Another item of considerable moment, not to be found in the original Hippocratic oath, is that of solid and continuous medical education (paragraph 8). This rule is

21 Pines, op. cit., note 19 above, pp. $2-4$.

22 Steinschneider, op. cit., note 2 above, p. 350.

23 S. Jarcho, 'Guide for physicians (Musar Harofim) by Isaac Judaeus (880?-932?)', Bull. Hist. Med., 1944, 15: 180-188. A. Bar-Sela and H. E. Hoff, 'Isaac Israeli's fifty admonitions to the physicians', J. Hist. Med., 1962, 17: 245-257.

${ }^{24}$ Hippocrates, Works, with an English translation by W. H S. Jones, 4 vols. [vol. 3 trans. by E. T. Withington], London, Heinemann, 1923, vol. 1, p. 295.

${ }^{26}$ Leibowitz, op. cit., note 20 above.

${ }^{28}$ K. Deichgräber, Der Hippokratische Eid, Stuttgart, Hippokrates Verlag, 1955, pp. 33-34. K. Deichgräber, Medicus Gratiosus, Wiesbaden, Steiner, 1970, pp. 85-107.

27 Jones, op. cit., note 24 above, vol. 1, p. 319.

28 "I urge you not to be too unkind, but to consider carefully your patient's superabundance or means. Sometimes give your service for nothing. .... And if there be an opportunity of serving one who is a stranger in financial straits, give full assistance to all such. For where there is love of man, there is also love of the art." 


\section{Texts and Documents}

at least alluded to in Precepts, ch. 13, ${ }^{29}$ where the physician is urged "to be free of the late learner's faults". This slightly obscure expression is a warning against ignorance and superficial training. In the words of our manuscript: "Above all, he should accustom himself to continual learning in order to help the body to health and should never weary of referring to books."

This medieval paraphrase is being presented as a stage in the development of medical deontology and an addition to the Hippocratic studies. With the advent of the monotheistic religions and the awakening of social responsibilities in the healing art, the ancient oath was enriched by some aspects in which the recently recovered manuscript has its share.

20 Jones, op. cit., note 24 above, vol. 1, p. 329. 